OPEN ACCESS

Edited by:

Scott Levick,

University of Sydney, Australia

Reviewed by:

Mihaly Boros,

University of Szeged, Hungary

Donna H. Wang,

Michigan State University,

United States

${ }^{*}$ Correspondence:

Susan D. Brain

sue.brain@kcl.ac.uk

Specialty section:

This article was submitted to

Integrative Physiology,

a section of the journal

Frontiers in Physiology

Received: 07 June 2018

Accepted: 17 August 2018 Published: 19 September 2018

Citation:

Kee Z, Kodji X and Brain SD (2018)

The Role of Calcitonin Gene Related Peptide (CGRP) in Neurogenic

Vasodilation and Its Cardioprotective

Effects. Front. Physiol. 9:1249.

doi: 10.3389/fphys.2018.01249

\section{The Role of Calcitonin Gene Related Peptide (CGRP) in Neurogenic Vasodilation and Its Cardioprotective Effects}

\author{
Zizheng Kee, Xenia Kodji and Susan D. Brain* \\ Section of Vascular Biology \& Inflammation, BHF Centre for Cardiovascular Research, School of Cardiovascular Medicine \\ and Sciences, King's College London, London, United Kingdom
}

Calcitonin gene-related peptide (CGRP) is a highly potent vasoactive peptide released from sensory nerves, which is now proposed to have protective effects in several cardiovascular diseases. The major $\alpha$-form is produced from alternate splicing and processing of the calcitonin gene. The CGRP receptor is a complex composed of calcitonin like receptor (CLR) and a single transmembrane protein, RAMP1. CGRP is a potent vasodilator and proposed to have protective effects in several cardiovascular diseases. CGRP has a proven role in migraine and selective antagonists and antibodies are now reaching the clinic for treatment of migraine. These clinical trials with antagonists and antibodies indicate that CGRP does not play an obvious role in the physiological control of human blood pressure. This review discusses the vasodilator and hypotensive effects of CGRP and the role of CGRP in mediating cardioprotective effects in various cardiovascular models and disorders. In models of hypertension, CGRP protects against the onset and progression of hypertensive states by potentially counteracting against the pro-hypertensive systems such as the renin-angiotensin-aldosterone system (RAAS) and the sympathetic system. With regards to its cardioprotective effects in conditions such as heart failure and ischaemia, CGRP-containing nerves innervate throughout cardiac tissue and the vasculature, where evidence shows this peptide alleviates various aspects of their pathophysiology, including cardiac hypertrophy, reperfusion injury, cardiac inflammation, and apoptosis. Hence, CGRP has been suggested as a cardioprotective, endogenous mediator released under stress to help preserve cardiovascular function. With the recent developments of various CGRP-targeted pharmacotherapies, in the form of CGRP antibodies/antagonists as well as a CGRP analog, this review provides a summary and a discussion of the most recent basic science and clinical findings, initiating a discussion on the future of CGRP as a novel target in various cardiovascular diseases.

Keywords: CGRP, neurogenic vasodilation, rodents, humans, hypertension, heart failure

\section{INTRODUCTION}

Calcitonin gene-related peptide (CGRP) was first identified in 1982 (Amara et al., 1982). It was soon established that the neuropeptide is a potent vasodilator and a transmitter in the peripheral and central nervous systems (Rosenfeld et al., 1983; Brain et al., 1985), resulting in their predicted roles in pain and cardiovascular regulation (Rosenfeld et al., 1983). It was soon realized that CGRP 
release in trigeminal neurons is associated with control of cerebral vascular tone and plays a role in migraine (O'Connor and van der Kooy, 1988; Edvinsson et al., 2012). As such, drugs targeting CGRP are currently being investigated for use clinically for the treatment of migraine. The first non-peptide CGRP antagonist, BIBN 4096 BS, was shown to be effective in animals and humans (Doods et al., 2000; Olesen et al., 2004). There are currently a number of CGRP monoclonal antibodies and antagonists in development which are showing good efficacy for migraine, with up to $32 \%$ of patients being completely relieved of symptoms. These drugs are currently undergoing approval for the treatment of migraine. However, as evidence suggests that CGRP possesses protective properties in various cardiovascular diseases (Smillie et al., 2014; Aubdool et al., 2017), there are concerns regarding cardiovascular safety despite minimal cardiovascular issues being observed in clinical trials to date (Paemeleire and MaassenVanDenBrink, 2018; Raffaelli and Reuter, 2018). This review aims to summarize knowledge on the potential role of CGRP in cardiovascular disease to aid the discussion of potential adverse effects of anti-CGRP treatments as well as to guide the developments of novel CGRP-dependent targets for various cardiovascular conditions.

\section{CGRP AND RECEPTOR}

\section{CGRP Synthesis and Structure}

Calcitonin gene-related peptide is a 37 amino acid peptide, produced by alternative splicing of the calcitonin gene (CALCA) (Amara et al., 1982; Rosenfeld et al., 1983; Figure 1). Human CGRP exists in $\alpha$ and $\beta$ forms, which share $94 \%$ structural similarity (Zaidi et al., 1990), with different residues at positions 3, 22, and 25. $\beta$-CGRP is transcribed from a separate CALCB gene, which has been proposed to be the result of a duplication of the alpha gene (Alevizaki et al., 1986). Both $\alpha$-CGRP and $\beta$-CGRP have comparable biological roles, but $\alpha$-CGRP is the principal form and is found in the central and peripheral nervous systems and is the primary subject of this review (Russell et al., 2014), while $\beta$-CGRP plays a larger role in enteric transmission (Mulderry et al., 1985). The expression of calcitonin and CGRP mRNA is tissue-specific, and CGRP mRNA is produced by splicing the first three exons to the fifth and sixth exons of CALCA (Amara et al., 1982). The translated CGRP protein then undergoes post-translational modification and protease cleavage to generate the mature peptide. This process is illustrated in Figure 1.

\section{Storage, Release and Metabolism}

Calcitonin gene-related peptide is localized throughout the peripheral and central sensory nervous system as well as other locations in the brain (Rosenfeld et al., 1983; Terenghi et al., 1985). Although CGRP is mostly associated with A $\delta$ and C fiber sensory nerves (Gibbins et al., 1985; Lundberg et al., 1985), immunostaining approaches demonstrated the presence of CGRP in association with smooth muscles in the heart and vasculature (Rosenfeld et al., 1983; Franco-Cereceda et al.,
1987; Csillik et al., 1993), suggesting the potential sensory and cardiovascular roles of CGRP. GGRP synthesis mainly occurs in the dorsal root ganglion (DRG) (Deng and Li, 2005) where the pro-peptide is then cleaved to the active form and stored in large dense-core vesicles at the sensory nerve terminals, where CGRP is commonly stored and co-released with substance P (Gulbenkian et al., 1986; Brain and Grant, 2004; Schlereth et al., 2016). Exocytosis leading to release is mediated by calcium-dependent pathways following nerve depolarization (Matteoli et al., 1988; Russell et al., 2014). Although release can be mediated in response to pressor substances, such as the sympathetic noradrenergic transmitter and the hypertensive mediator angiotensin (see section: Hypertension), their release is most commonly associated with the activation of these sensory fibers, either by electrical stimulation or by the activation of transient receptor potential (TRP) channels, as shown in Figure 1 (Escott and Brain, 1993; Russell et al., 2014). TRP channels are a superfamily of non-selective cation-permeable channels, that are each activated by a range of agonists and stimuli (Zheng, 2013). The precise circumstances under which CGRP is released remain under study. Of particular significance to sensory nerves are TRPV1 (transient receptor potential vanilloid 1) and TRPA1 (transient receptor potential ankyrin 1) channels, which are highly co-expressed in CGRP-positive fibers (Kobayashi et al., 2005). TRPV1 is activated by the chili pepper extract capsaicin as well as noxious stimuli such as heat or acidity, acting as transducers of thermal pain (Caterina et al., 1997; Venkatachalam and Montell, 2007), while TRPA1 channels are activated by a distinct subset of agents, including pungent extracts, such as mustard oil and cinnamaldehyde, noxious cold, as well as by endogenous reactive oxygen species and cellular stress mediators (Bandell et al., 2004; Viana, 2016). Both TRPV1 and TRPA1 channels have been shown to trigger CGRP release by increasing intracellular calcium levels in vitro (Quallo et al., 2015; Shang et al., 2016; Eberhardt et al., 2017) and in vivo, producing neurogenic vasodilation (Pozsgai et al., 2012; Aubdool et al., 2016). In human skin, capsaicin produces a flare that is mediated by CGRP (Van der Schueren et al., 2008). TRPV1 was shown to contribute to cardiovascular pathophysiology under certain conditions, such as high fat diet, but not in a CGRPdependent manner (Marshall et al., 2013). Moreover, TRPA1 has no observed contribution to blood pressure regulation (Bodkin et al., 2014). The depletion of CGRP positive nerves is possible by repeated TRPV1 agonist application, such as capsaicin and resiniferatoxin, resulting in the desensitization of sensory nerves, which is often used as a blocking strategy (Jancsó et al., 1967; Bánvölgyi et al., 2005). Following its release and action, CGRP has a short half-life, with one study calculating it to have a biphasic clearance with a 6.9-min initial half-life and a 26.4 min slower decay (Kraenzlin et al., 1985). It is metabolized via proteases and possibly other mechanisms (Russell et al., 2014).

\section{CGRP Source and Plasma Levels}

The main source of plasma CGRP is thought to be due to a "spillover" from its release from the perivascular nerve endings, which may contribute to its vasodilatory role (Brain and Grant, 

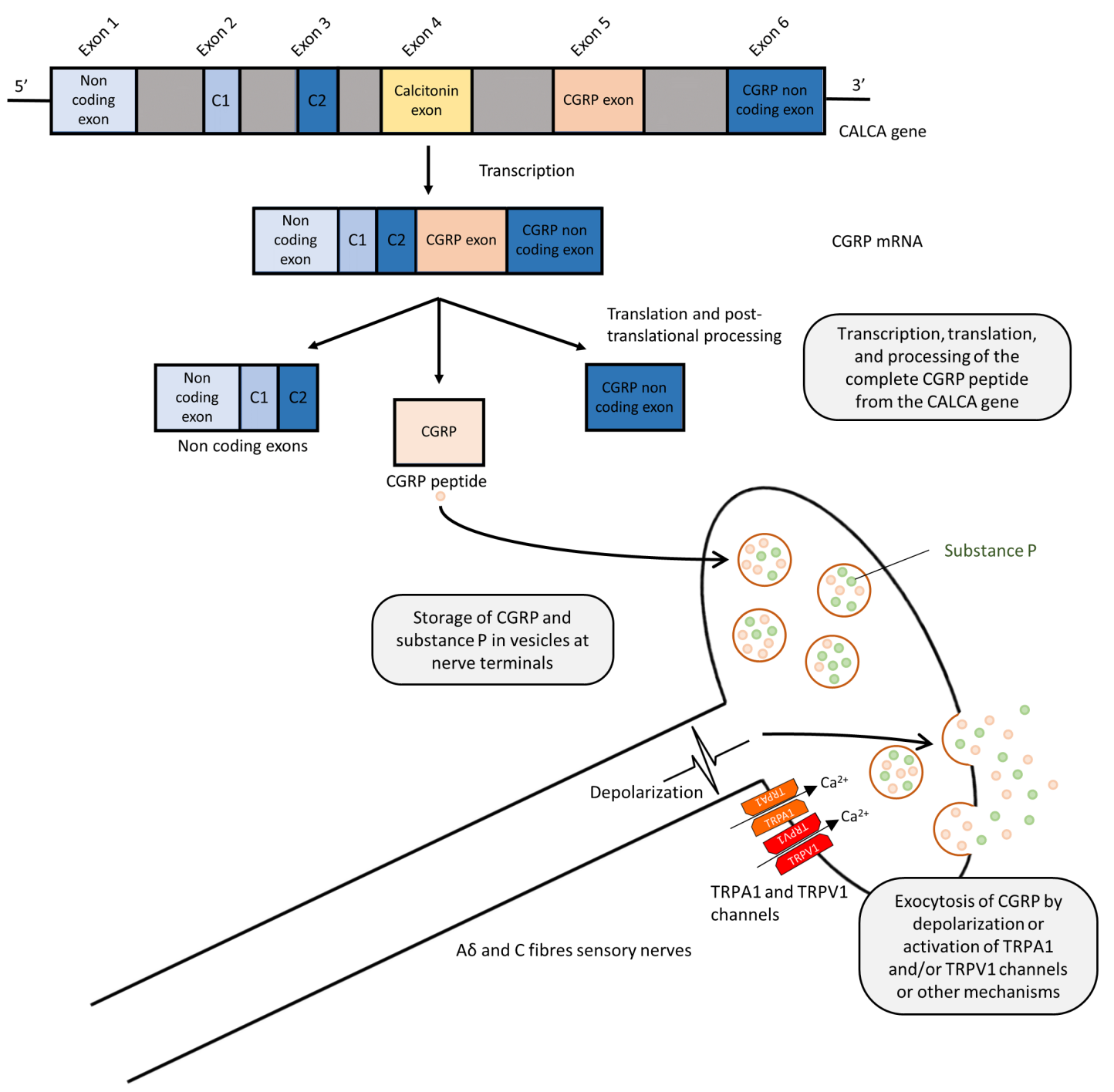

FIGURE 1 | Splicing and post-translational processing of the complete CGRP peptide from the CALCA gene, vesicular packaging, and release from sensory nerves. Exons 1,2,3,5, and 6 of the CALCA gene are transcribed to form the CGRP mRNA which is then translated to protein. Post-translational cleavage produces the complete 37-amino acid CGRP peptide. CGRP is packaged and co-released with substance P in a calcium dependent manner due to depolarization or via activation of TRPA1 or TRPV1 channels.

2004). Circulating plasma levels in healthy volunteers are low (in the $\mathrm{pg} / \mathrm{ml}$ range), which in part is due to the rapid metabolic clearance of plasma CGRP (Kraenzlin et al., 1985). However, CGRP is naturally elevated in pregnancy where it is proposed to regulate utero/placental blood flow and other vascular changes (Dong et al., 2002). Plasma levels are elevated in certain pathological states, such as sepsis (Joyce et al., 1990a), where hypotension poses a major comorbidity. In migraine, only cerebral vessel and ipsilateral jugular vein levels, but not plasma levels, of CGRP are elevated (Goadsby et al., 1990; Edvinsson and Goadsby, 1995; Ashina et al., 2000; CernudaMorollón et al., 2015; Messlinger, 2018). Changes in plasma CGRP levels under pathological conditions are further discussed in respective sections. A range of non-neuronal cells have also been shown to synthesize CGRP, including lymphocytes and monocytes (Bracci-Laudiero et al., 2002; Wang et al., 2002; Linscheid et al., 2004). Endothelial cells have also been shown to synthesize and store CGRP in Weibel-Palade bodies where it may play a role in autoregulation of hemodynamics (Ozaka et al., 1997; Doi et al., 2001). Thus, there appear to be multiple sources of CGRP, but the neuronal sources are considered the most important in terms of cardiovascular physiology and pathology and indeed the relevance of some of the cellular sources is unknown.

\section{The CGRP Receptor}

The biological effects of CGRP are mainly mediated by its associated receptor. The complex nature of the CGRP receptor has been discussed in-depth recently in Hay et al. (2018). Following an intense period of research, it is now realized that 


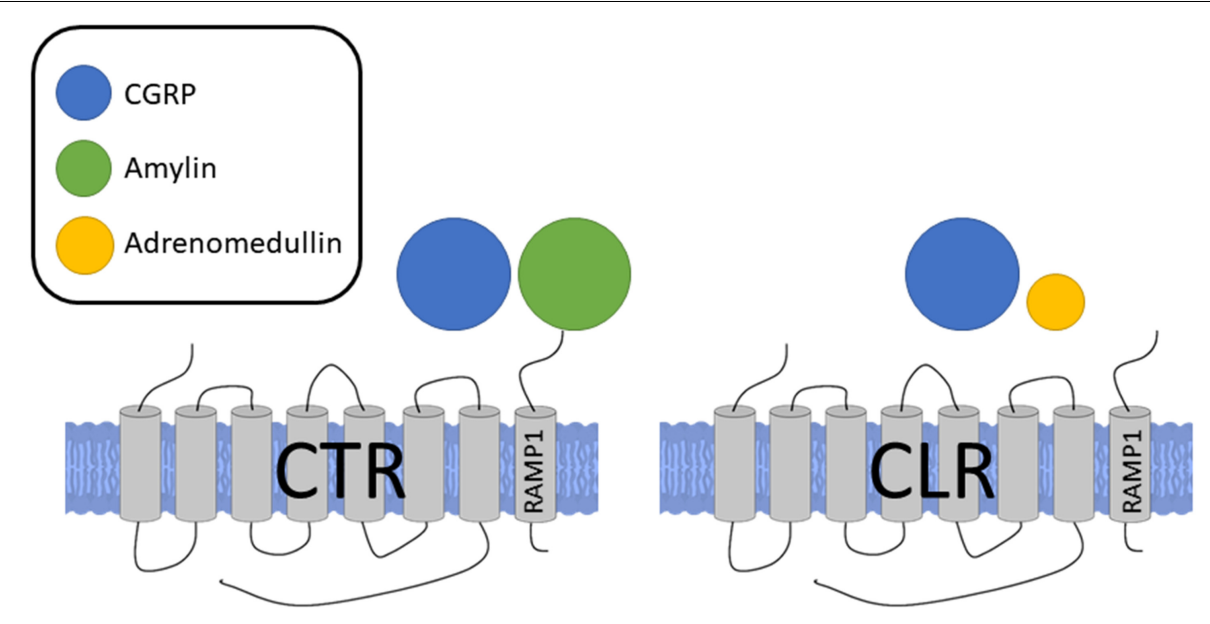

FIGURE 2 | Receptors for CGRP, formed by association of either CTR or CLR with RAMP1. Sizes of different agonists indicate relative potencies at each receptor complex. CGRP and amylin are equally potent at the CTR/RAMP1 receptor complex while CGRP is more potent at the CLR/RAMP1 complex, the classical CGRP receptor.

the canonical CGRP receptor is a complex of calcitonin receptorlike receptor (CLR), a class B G-protein coupled receptor (GPCR) and a receptor activity modifying protein 1 (RAMP1), a member of the single transmembrane RAMP family (RAMPs 1, 2, or 3), and the receptor component protein (RCP) (McLatchie et al., 1998; Evans et al., 2000; Dickerson, 2013; Russell et al., 2014). RAMP1 is important in the transport of CLR to the plasma membrane where they form a heterodimer to create the full receptor complex and agonist binding (Kuwasako et al., 2006; Booe et al., 2018), while RCP is important in the intracellular G-protein signaling (Evans et al., 2000). However, due to the promiscuous nature of RAMP, it is now thought that CGRP may also be able to signal via other non-canonical receptors of related peptide members, such as the CLR/RAMP3 combination, which is an adrenomedullin receptor $\left(\mathrm{AM}_{2}\right)$ (Qi et al., 2011; Russell et al., 2014) although at a lower potency. Adrenomedullin additionally has some affinity for CGRP receptors, which could account for some of the heterogeneous results and difficulty in early attempts at classifying the CGRP receptor (Moreno et al., 2002). This model has been validated experimentally where CGRP binding correlates well to RAMP1 mRNA levels (Chakravarty et al., 2000). The RAMP proteins regulate the transport of CLR from the endoplasmic reticulum to the plasma membrane (McLatchie et al., 1998) and it has been shown that the cytoplasmic tails of RAMP proteins are crucial for intracellular trafficking of CLR to the membrane. To add to the complexity, more recently it has also been found that association of the calcitonin receptor (CTR) and RAMP1 also forms a CGRP responsive receptor. Although the CTR/RAMP complex was previously described as amylin receptors, it is now shown that CGRP and amylin are equally potent at the CTR/RAMP1 (AMY 1 ) receptor (Hay et al., 2018; Figure 2). Indeed, the expression of CTR/RAMP1 is suggested to be of potential importance in the sensory trigeminal system, where it may play a role in migraine pain as shown by its expression and histology in rats and humans (Hay et al., 2018). CTRs can promote RAMP translocation to the cell surface and there may be competition between RAMPs, leading to biased formation of one receptor complex over another (Bühlmann et al., 1999). Downstream of the receptor activation, the CGRP receptor complex is coupled to $G_{\alpha s}$ and $G_{\alpha q}$, and the effects of agonist binding are mediated by downstream signaling through these G proteins depending on their sites of action. Using a HEK293 cell line, it was shown that CGRP exhibits biased agonism, favoring the $G_{\alpha s}$ pathway and thus vasodilation (Weston et al., 2016) where CGRP triggers nitric oxide (NO) production in the endothelial cells, acting to relax the underlying vascular smooth muscles, while PKA activation in the vascular smooth muscles also independently mediate $\mathrm{NO}$-independent vasodilation by hyperpolarisation of the smooth muscle cell. Thus, while the pharmacological profile of the CLR receptor expressed on the cell surface is dependent on the RAMP subtype that accompanies it, the pharmacology is complex, potentially involving other CGRP receptors.

\section{VASODILATOR EFFECTS OF CGRP}

Physiologically, intravenous infusion of CGRP in humans induces a decrease in blood pressure through its vasodilatory effects as well as a positive chronotropic effect, as demonstrated in humans (Struthers et al., 1986), in addition to altering regional blood flow, as observed in human subjects (Jäger et al., 1990). The administration of CGRP by intravenous infusion also increases blood flow to skin (in support of its microvascular potency, resulting in an observable facial flushing) and brain, measured by laser doppler imaging (Jäger et al., 1990). CGRP can also have effects on other organ systems; for example, in the kidneys, CGRP induced relaxation and increase in cAMP levels result in increased blood flow and a subsequent rise in glomerular filtration that has a significant effect on renal hemodynamics (Kurtz et al., 1989; Edwards and Trizna, 1990). CGRP also affects 
coronary blood flow by its direct action on the vasculature, independent of any systemic reflexes due to the changes in blood pressure or heart rate, as measured in humans by angiography (Ludman et al., 1991). Of note, as discussed above, the vasorelaxing effects of CGRP do appear to be predominantly at the peripheral level in small vessels rather than large arteries (Marshall et al., 1988; Sekiguchi et al., 1994). The highly potent effects of CGRP on multiple cardiovascular functions highlight its potential contribution in various cardiovascular diseases.

CGRP has a range of regulatory effects that have been studied in rodents, as described below. However, it has also been shown to generally mediate its vasodilator activity independently of cyclo-oxygenase products, such as prostacyclin (Brain et al., 1985), by comparison, CGRP does have a nitric oxide-dependent vasodilator mechanism in certain tissues in a manner that appears neither species or tissuedependent (Russell et al., 2014). There is also a distinct but reported interaction whereby the CGRP receptor reduces the effects of the potent constrictor agent endothelin through an interaction involving G-protein $\beta \gamma$ subunit (Meens et al., 2012).

\section{CGRP IN CARDIOVASCULAR DISEASE}

\section{Hypertension}

Despite its role as a vasodilator, there is no consensus on the levels of CGRP in hypertension. In human patients with hypertension, plasma CGRP has been found to be higher (Masuda et al., 1992), unchanged (Schifter et al., 1991), and decreased (Edvinsson et al., 1989; Portaluppi et al., 1992) as reviewed by several groups (including Dong et al., 2002; Smillie and Brain, 2011). It has been suggested that these contradictory observations may be due to differences in sampling and radioimmunoassays used as well as due to the heterogeneity in duration, severity, and treatment of the varying hypertensive populations studied (Bell and McDermott, 1996). However, in patients with secondary hypertension, plasma CGRP levels were decreased after adrenalectomy to treat the underlying condition (Masuda et al., 1992). This would indicate that CGRP is a compensatory response to elevated blood pressure and can become depleted or potentially inhibited as disease progresses (Dong et al., 2002; Smillie et al., 2014).

In CGRP knockout (KO) mice, blood pressure was shown to be significantly elevated in some (Kurihara et al., 2003; Mai et al., 2014), but not all strains (Smillie et al., 2014). The role of CGRP has been studied in a range of different rodent models of hypertension. This includes those that involve raising the levels of pressor agent angiotensin. In one study where baseline blood pressure was not affected in CGRP $\mathrm{KO}$ mice, angiotensin administration for up to 28 days led to enhanced hypertension, alongside aortic hypertrophy and decreased endothelial nitric oxide synthase expression (Smillie et al., 2014). In the rat angiotensin-induced hypertension model, the co-administration of subdepressor doses of exogenous CGRP for 6 days significantly reduced blood pressure (Fujioka et al., 1991). However, in a 10-day study, angiotensin increased CGRP receptor expression but not endogenous CGRP levels ( $\mathrm{Li}$ and Wang, 2005). In one CGRP KO mouse strain, plasma renin was higher in $\mathrm{KO}$ mice and $\mathrm{AT}_{1}$ blockers were found to have greater effects (Li et al., 2004). Thus, there is good evidence that CGRP plays a protective role against the pathophysiology and onset of hypertension (Smillie and Brain, 2011). This was further shown in the spontaneously hypertensive rat model, where treatment with angiotensin-converting enzyme inhibitors increased the density of CGRP innervation and expression, restoring CGRP nerve function and vasodilator responses (Kawasaki et al., 1999). This adds to the concept that CGRP interacts with RAAS to modulate and maintain blood pressure.

To further understand the mechanisms, deoxycorticosterone (DOC) salt and two-kidney, one-clip (2K1C) rat hypertensive models have been utilized. CGRP expression (mRNA) and plasma levels were elevated, and $\mathrm{CGRP}_{8-37}$ or capsaicin depletion of CGRP (to deplete and thus lose/block the CGRP component) led to further increases in the already elevated blood pressure in these models (Supowit et al., 1997; Deng et al., 2003). In spontaneously hypertensive rats and phenol induced hypertensive models, CGRP expression (mRNA) and plasma levels were instead decreased, but $\mathrm{CGRP}_{8-37}$ or capsaicin pre-treatment had no effect on blood pressure. Hence, it is clear that the loss of CGRP contributes to the development of hypertension (Supowit et al., 1993; Deng et al., 2004).

It is perhaps not surprising that CGRP interacts indirectly with a range of other vasoactive mediators. Early evidence from the rat mesentery indicated that noradrenaline released from sensory nerves could influence release of CGRP and vice versa; indicating the potential of CGRP to be involved in regulating vascular resistance (Kawasaki et al., 1998). Immunohistochemical staining revealed high concentrations of CGRP immunoreactive fibers in the rat mesenteric artery, the intensity of which decreased after pre-treatment with capsaicin, confirming the expression of CGRP in this vascular bed (Kawasaki et al., 1990). Then, subdepressor doses of CGRP were co-administered with norepinephrine, causing a significant reduction in blood pressure in norepinephrine-induced hypertensive rats (Fujioka et al., 1991). Studies blocking CGRP nerve transmission by $\mathrm{CGRP}_{8-37}$ or capsaicin depletion showed increased vasoconstriction caused by periarterial nerve stimulation, further showing that exogenous CGRP can attenuate noradrenergic-induced constriction (Takenaga and Kawasaki, 1999). Together, these studies suggest that CGRP has the ability to inhibit sympathetic nervous activity. Indeed, it is considered that perivascular sensory nerves and sympathetic nerves act alongside each other, in rodents at least, to maintain peripheral vascular tone.

Altogether, previous studies have shown that CGRP plays a protective role in the onset and progression of hypertension in rodents. By comparison, the physiological role of CGRP in the normotensive situations in rodents remains unclear, as some knockout mouse strains are mildly hypertensive, 
indicating a physiological role, as previously mentioned. Usually, these have deletion in the calcitonin gene, in addition to the CGRP, gene (Smillie and Brain, 2011). However, the cardiovascular effects of CGRP blockade have been investigated in rat models (Juhl et al., 2007; Zeller et al., 2008) which found no change in cardiovascular parameters. Hence the evidence mainly from animal models, to date, indicates that CGRP can interact with key pro-hypertensive systems to counterbalance the onset of cardiovascular disease (see Table 1)

\section{Ischemia}

CGRP is released endogenously in response to ischemia (Mishima et al., 2011) and is suggested to play a role in preconditioning and protection against reperfusion injury. It has been shown in humans that plasma CGRP expression is upregulated following acute myocardial infarction (Roudenok et al., 2001). In rat models, CGRP induced preconditioning has been shown to be able to protect and attenuate reperfusion injury in heart, brain, and hepatic tissue. These responses were abolished by $\mathrm{CGRP}_{8-37}$, indicating that CGRP is a key central mediator of preconditioning and acts in a protective role (Li et al., 1996; Song et al., 2009; Liu et al., 2011). The release of CGRP by TRPV1 is also implicated. In a rat model of ischemia/reperfusion, administration of ruthenium red, a non-selective TRP antagonist, abolished the protective effects of remote limb preconditioning, as measured by infarct size, the release of lactate dehydrogenase, and creatine kinase (Singh et al., 2017). The protective effect is also lost with $\mathrm{CGRP}_{8-37}$ administration (Wolfrum et al., 2005). This finding is in line with previous studies that have shown plasma CGRP and mRNA levels to be increased after remote limb ischemic preconditioning, suggesting a cardioprotective mechanism involving TRPV1 mediated CGRP release (Gao et al., 2015). CGRP also protects against ischemia/reperfusion injury in the liver, as measured by alanine aminotransferase and glutamate-lactate dehydrogenase in one study (Song et al., 2009). A summary is shown in Table $\mathbf{1}$. However, the mechanism through which CGRP mediates this protective effect remains to be elucidated.

\section{Heart Failure}

In the heart, CGRP-containing nerves are densely distributed around the coronary arteries, ventricular muscle, and the conduction system, thus ideally placed to play a functional role in the maintenance of cardiac homeostasis (Mulderry et al., 1985; Russell et al., 2014). Reported levels of plasma and tissue CGRP in heart failure, as for hypertension, are confusing and in general, poorly described. One study in children with congenital heart disease found that CGRP levels are higher in those with heart failure compared to healthy controls and levels were also positively correlated with the severity of disease (Hsu et al., 2005). However, in adult patients with chronic congestive heart failure, CGRP levels were found to be lower (Taquet et al., 1992). By comparison, increased CGRP levels in blood plasma have been observed in volume overload heart failure in humans, suggesting that it has the potential to act as a compensatory mechanism (Preibisz, 1993). In an in vitro model, the administration of the TRPV1 agonist, capsaicin, caused the release of CGRP which had positive inotropic and chronotropic effects on guinea pig atrium that were subject to tachyphylaxis as well as being abolished by capsaicin pretreatment, to desensitize the nerve (Lundberg et al., 1984). Similar results were observed in a rat model, where CGRP release by another proposed TRPV1 agonist, rutaecarpine, protects against isoprenaline-induced heart failure by relieving cardiac hypertrophy and cardiac apoptosis. These effects were also attenuated with capsaicin pre-treatment, suggesting that CGRP production and release protects against heart failure (Lundberg et al., 1984; Li et al., 2010). This is in keeping with results in the CGRP KO mouse using a transverse aortic constriction (TAC) model (Li et al., 2013). The vasodilator activity of CGRP is considered to decrease cardiac afterload and improve cardiac function (Struthers et al., 1986). In the guinea pig atrium, CGRP was found to increase the L type calcium current by stimulation of adenylyl cyclase leading to positive inotropy, but the same was not found in ventricular myocytes (Nakajima et al., 1991). This finding is also consistent with earlier studies that showed high binding of radiolabelled CGRP ligands in the rat atrium but not the ventricles (Sigrist et al., 1986) and that cAMP levels in the atria significantly increases following administration of CGRP (Ishikawa et al., 1988). The effects of CGRP on intracellular calcium dynamics also appear to be mediated by the PI3K/Akt pathway. Inhibition of PI3K in rat myocytes in vivo abolished CGRP induced increases in calcium release and prolonged calcium sequestration (Al-Rubaiee et al., 2013). A summary is shown in Table 1.

The concept that exogenous administration of CGRP may be beneficial has been investigated, mainly using the CGRP peptide which, as discussed, has a short half-life. CGRP administration in humans causes an increase in catecholamine levels in the blood, and the inotropic effects of CGRP have been associated with increased plasma norepinephrine and epinephrine (Tortorella et al., 2001). Moreover, the positive inotropy was blocked by adrenergic antagonists but not the hypotensive and chronotropic actions (Gennari and Fischer, 1985). As heart failure often leads to activation of the baroreceptor reflex and sympathetic activity (Wang et al., 2004), the response to CGRP was separated by ganglionic and adrenergic blockade in one canine study. It was found that ganglionic antagonist hexamethonium did not affect CGRP mediated inotropy and vasodilation but the adrenergic antagonist timolol attenuated the heart response to CGRP (Katori et al., 2005). Thus, sympathetic activation is suggested to be, at least in part, an indirect effect of CGRP which enhances cardiac function through systemic vasodilation. In a rat coronary ligation model, CGRP was found to have a dilatory effect, but the response to CGRP in the basilar artery was attenuated. This led to the suggestion that this would be beneficial in heart failure as arterial perfusion pressure would be maintained despite the decreased cardiac output (Bergdahl et al., 1999). Additionally, in a canine model, CGRP administration increased coronary flow and decreased coronary resistance without affecting heart rate, presumably due to its vasodilatory actions on the coronary vasculature (Joyce et al., 
1990b). By comparison, in chronic heart failure, there is attenuation of the adrenergic system. In another canine study, the capacity of sympathetic neurons to release noradrenaline was reduced resulting in reduced sympathetic compensation in heart failure (Cardinal et al., 1996). Additionally, desensitization to catecholamines occurs in multiple points of the adrenoceptor cascade, including decreased distribution and amount of adrenoceptors, decreased agonist affinity, and decreased the activity of adenylyl cyclase (Vatner et al., 1996). Thus, in chronic heart failure, the indirect sympathetic effects of CGRP are likely to be dampened. It has been suggested that CGRP acts indirectly through sympathetic signaling as a compensatory mechanism to increased demand, such as during exercise where CGRP levels are found to be increased (Lind et al., 1996). However, in heart failure where adrenergic transmission becomes downregulated, one possibility may be that CGRP may no longer reduce afterload efficiently to improve cardiac output (Katori et al., 2005). Importantly though, CGRP administration has still been shown to be beneficial in the few human studies carried out to date (Gennari et al., 1990; Anand et al., 1991; Ferrari et al., 1991; Shekhar et al., 1991), so more studies are needed.

TABLE 1 | The role and protective effects of CGRP in hypertension, ischemia, and heart failure.

\begin{tabular}{|c|c|c|c|c|}
\hline Disease & Role of CGRP & Mechanisms of protection & Evidence in animal models & References \\
\hline \multirow[t]{5}{*}{ Hypertension } & $\begin{array}{l}\text { CGRP reduces blood pressure } \\
\text { in pathologic states but is not } \\
\text { involved in physiological } \\
\text { regulation of blood pressure }\end{array}$ & $\begin{array}{l}\text { Modulation of RAAS to } \\
\text { maintain blood pressure }\end{array}$ & $\begin{array}{l}\text { Plasma renin is higher in CGRP KO } \\
\text { mice }\end{array}$ & Li et al., 2004 \\
\hline & & & $\begin{array}{l}\text { Treatment with ACE inhibitors on } \\
\text { spontaneously hypertensive rats } \\
\text { restores CGRP function and responses }\end{array}$ & Kawasaki et al., 1999 \\
\hline & & $\begin{array}{l}\text { Inhibition of sympathetic activity } \\
\text { reduces blood pressure }\end{array}$ & $\begin{array}{l}\text { In a rat model, CGRP antagonist or } \\
\text { capsaicin depletion potentiates } \\
\text { vasoconstriction induced by periarterial } \\
\text { nerve stimulation }\end{array}$ & Takenaga and Kawasaki, 1999 \\
\hline & & & $\begin{array}{l}\text { CGRP KO mice had increased } \\
\text { hypertension and aortic hypertrophy in } \\
\text { an angiotensin II model }\end{array}$ & Smillie et al., 2014 \\
\hline & & & $\begin{array}{l}\alpha \text { CGRP decreased arterial pressure } \\
\text { while CGRP } 8-37 \text { increased it in } \\
\text { angiotensin II treated rats }\end{array}$ & Li and Wang, 2005 \\
\hline \multirow[t]{3}{*}{ Heart failure } & $\begin{array}{l}\text { CGRP is released in a } \\
\text { compensatory manner in } \\
\text { response to heart failure and } \\
\text { acts in a protective manner }\end{array}$ & $\begin{array}{l}\text { Vasodilation decreases } \\
\text { afterload to enhance stroke } \\
\text { volume }\end{array}$ & $\begin{array}{l}\text { In a congestive heart failure rat model, } \\
\text { CGRP induces vasodilation of blood } \\
\text { vessels in vitro }\end{array}$ & Bergdahl et al., 1999 \\
\hline & & & $\begin{array}{l}\text { CGRP infusion in dogs increased } \\
\text { coronary flow and decreased coronary } \\
\text { resistance and blood pressure }\end{array}$ & Joyce et al., 1990b \\
\hline & & $\begin{array}{l}\text { Positive inotropic effects } \\
\text { increase stroke volume and } \\
\text { ejection fraction }\end{array}$ & $\begin{array}{l}\text { CGRP infusion in dogs increased } \\
\text { cardiac contractility and is blocked by B } \\
\text { receptor antagonists. As isolated } \\
\text { myocytes show no response to CGRP, } \\
\text { it is suggested CGRP mediates positive } \\
\text { inotropy through sympathetic activation }\end{array}$ & Katori et al., 2005 \\
\hline \multirow[t]{3}{*}{ Ischemia } & $\begin{array}{l}\text { CGRP is released, by the } \\
\text { activation of TRPV1 channels, } \\
\text { in ischemia where it exerts } \\
\text { protective effects against } \\
\text { reperfusion injury and mediates } \\
\text { preconditioning }\end{array}$ & $\begin{array}{l}\text { The mechanism of the } \\
\text { protective effects of CGRP is } \\
\text { unclear. CGRP is purported to } \\
\text { play a role in ischemic } \\
\text { preconditioning and is } \\
\text { protective against reperfusion } \\
\text { injury }\end{array}$ & $\begin{array}{l}\text { In a rat model of remote hind limb } \\
\text { preconditioning, TRPV and CGRP } \\
\text { inhibitors abolished protective effects of } \\
\text { preconditioning }\end{array}$ & Singh et al., 2017 \\
\hline & & & $\begin{array}{l}\text { CGRP protects against } \\
\text { ischemia-reperfusion injury in a rat liver } \\
\text { ex vivo model }\end{array}$ & Song et al., 2009 \\
\hline & & & $\begin{array}{l}\text { CGRP decreases infarct size in a rat } \\
\text { mesenteric artery occlusion model. } \\
\text { PKC inhibition abolishes the effect of } \\
\text { CGRP, and it is suggested myocardial } \\
\text { PKC } \varepsilon \text { activation by CGRP mediates } \\
\text { protection }\end{array}$ & Wolfrum et al., 2005 \\
\hline
\end{tabular}

Mechanisms by which CGRP exerts its effects and evidence in animal studies is also summarized. 


\section{THERAPEUTIC APPROACHES INVOLVING THE CGRP PATHWAY}

\section{Effects of CGRP Antagonists and Antibodies That Benefit Migraine on the Baseline Regulation of Human Blood Pressure}

Recently, various pharmacological tools targeting CGRP have been developed for the treatment of migraine. CGRP antagonists such as BIBN 4096 BS (Olcegepant) have been used in migraine to good effect (Olesen et al., 2004) but were not further developed despite showing efficacy (Yao et al., 2013). Importantly, the safety of these compounds has been studied in single dose (Edvinsson, 2005) and longer-term daily dosing (Ho et al., 2014) and no cardiovascular adverse events were detected. However, the studies were relatively small and short-term, lasting no more than 12 weeks, as most of the treatments for migraine are administered acutely for short periods of time and the timeframes of clinical studies reflect this. Recently, longer studies involving antibodies have also progressed without cardiovascular side effects. In one study specifically examining cardiovascular and hemodynamic effects of CGRP antagonism in humans, no clinically significant changes in blood pressure, heart rate, or ECG were detected over 24 weeks (Bigal et al., 2014). There are currently four monoclonal antibodies, against the CGRP peptide or receptor, undergoing phase 2 or 3 clinical trials. At the time of writing, there has not been any cardiovascular adverse event or significant changes in cardiovascular measurements such as electrocardiogram (ECG) attributable to treatment. The findings of the latest trials are detailed (see Table 2). To date, most studies have been performed on normal, healthy subjects and do not address how CGRP blockade may affect a compromised cardiovascular system. Considering the findings in the pre-clinical models consistently showing exacerbation of underlying cardiovascular pathologies with CGRP inhibition it is important to address whether CGRP blockade may exacerbate current cardiovascular disease or increase the severity of cardiovascular events that happen and also whether there is a difference between monoclonal antibodies targeted toward the CGRP receptor or peptide (MaassenVanDenBrink et al., 2016). Emerging evidence begins to take this into account, as a recent clinical study investigated the effect of intravenous erenumab administration in patients with stable angina. Consistently, such acute administration did not show a significant difference in exercise-induced angina or ischemia, consistent with the minimal effect of CGRP inhibition in acute conditions (Depre et al., 2018). However, erenumab is currently the only antibody that blocks the CGRP receptor and the results may not be applicable to inhibition of the CGRP ligand. Indeed, further study on whether chronic CGRP depletion adversely affects subjects with cardiovascular disease will be important to establish cardiovascular safety of these drugs, especially as migraine is associated with an increased risk of cardiovascular disease (Sacco and Kurth, 2014).

\section{CGRP Pharmacotherapy}

The administration of a CGRP agonist will act to enhance CGRP signaling and may prove to be beneficial in cardioprotection. As discussed above, CGRP plays several roles in cardio-protection against hypertension, ischemia, and heart failure. Thus, it follows that administration of exogenous CGRP may have beneficial effects in these conditions. However, one of the major drawbacks of CGRP is that, as a peptide, it cannot be delivered orally. In addition, it has a short half-life and is rapidly cleared from the blood. Exogenous CGRP has been studied

TABLE 2 | Current monoclonal antibodies undergoing clinical trials and latest findings, in terms of cardiovascular adverse events and changes in cardiovascular perimeters.

\begin{tabular}{|c|c|c|c|c|c|}
\hline Name & Target & Trial & Study length & Findings & Reference \\
\hline Eptinezumab (ALD403) & CGRP peptide & Phase 2 DBPC & 24 weeks & $\begin{array}{l}\text { No significant adverse events related to } \\
\text { treatment. No difference in vital signs } \\
\text { and ECG }\end{array}$ & Dodick et al., 2014 \\
\hline Fremanezumab (TEV-48125) & CGRP peptide & Phase 2b DBPC & 12 weeks & $\begin{array}{l}\text { No significant change in vital signs and } \\
\text { ECG }\end{array}$ & Bigal et al., 2015 \\
\hline Galcanezumab (LY2951742) & CGRP peptide & EVOLVE-1 Phase 3 DBPC & 10 months & $\begin{array}{l}\text { No significant change in vital signs or } \\
\text { increases in blood pressure. No } \\
\text { cardiovascular adverse events reported }\end{array}$ & Stauffer et al., 2018 \\
\hline
\end{tabular}


in patients with congestive heart failure, given by continuous intravenous infusion over $24 \mathrm{~h}$, and has been demonstrated to be beneficial to hemodynamic variables (Gennari et al., 1990). However, the effects were lost within $30 \mathrm{~min}$ of stopping therapy, concurring with the short half-life (Shekhar et al., 1991). Recently, an acylated $\alpha$ CGRP analog has been synthesized and shown to have a significantly longer half-life of $10.2 \mathrm{~h}$ using a diabetes model (Nilsson et al., 2016). The same peptide analog was later investigated in murine models of hypertension and heart failure. It was demonstrated that daily dosing with up to $100 \mathrm{nmol} / \mathrm{kg}$ protects against hypertension by attenuating cardiac remodeling, oxidative stress, and reduces blood pressure in an Ang-II model of hypertension. Renal function was also preserved, alongside upregulation of RAMP1. In an abdominal aortic constriction model of heart failure, the CGRP analog attenuated cardiac hypertrophy and apoptosis, demonstrating a beneficial effect of chronic CGRP treatment in heart failure over several weeks (Aubdool et al., 2017). In human tissue, this analog also demonstrated similar pharmacological effects to the native peptide, except for a slightly reduced potency but a longer plasma half-life means that it is potentially useful in research as well as therapy (Sheykhzade et al., 2018). Thus, CGRP analogs or agonism may be a viable pharmacological target for the treatment of cardiovascular diseases and warrants further study.

Future studies should be aimed at understanding the mechanisms involved in the protective effects and the relative contribution of the vasodilator compared with other activities of CGRP described above. It is also hoped that the results targeting the protective effects of CGRP act to incentivise studies into the synthesis of non-peptide CGRP agonists, which could potentially lead to an orally available agonist. This will truly allow the therapeutic potential of CGRP agonists to be evaluated clinically. Meanwhile, the possibility that chronic antagonist and antibody therapy leads to cardiovascular side effects will be evaluated in ongoing experimental medicine studies as well as patient observation of those now being given these new agents to treat migraine.

\section{CONCLUSION}

Calcitonin gene-related peptide is a potent vasodilator peptide released from sensory nerves. While it does not regulate

\section{REFERENCES}

Alevizaki, M., Shiraishi, A., Rassool, F. V., Ferrier, G. J., MacIntyre, I., and Legon, S. (1986). The calcitonin-like sequence of the beta CGRP gene. FEBS Lett. 206, 47-52. doi: 10.1016/0014-5793(86)81338-2

Al-Rubaiee, M., Gangula, P. R., Millis, R. M., Walker, R. K., Umoh, N. A., Cousins, V. M., et al. (2013). Inotropic and lusitropic effects of calcitonin gene-related peptide in the heart. Am. J. Physiol. Heart Circ. Physiol. 304, H1525-H1537. doi: 10.1152/ajpheart.00874.2012

Amara, S. G., Jonas, V., Rosenfeld, M. G., Ong, E. S., and Evans, R. M. (1982). Alternative RNA processing in calcitonin gene expression generates mRNAs encoding different polypeptide products. Nature 298, 240-244. doi: 10.1038/ 298240a0

Anand, I. S., Gurden, J., Wander, G. S., O’Gara, P., Harding, S. E., Ferrari, R., et al. (1991). Cardiovascular and hormonal effects of calcitonin gene-related peptide blood pressure or hemodynamics in healthy conditions, it has cardio-protective activities under pathological states. The protective actions of CGRP have been demonstrated in several rodent models of different cardiovascular diseases. CGRP was found to counteract pro-hypertensive systems to protect against hypertension. It remains unclear how important the vasodilator effects are in this. It is also known from studies including those carried out in humans that CGRP decreases afterload and increases inotropy, which is protective in heart failure. Finally, under ischemic stress, CGRP helps preserve cellular energetics, as well as having anti-apoptotic and anti-inflammatory effects. The effects of CGRP on the different pathologies are summarized in Table 1. Ultimately, CGRP is released and confers beneficial protective effects under pathological states.

Currently, CGRP therapy is used in the treatment of migraine, where antagonists and antibody inhibitors have shown good efficacy. No adverse cardiovascular effects of concern have been observed in studies to date. However, many of the safety studies on CGRP antagonists have not examined their effects on subjects with compromised cardiovascular systems. CGRP agonists may have therapeutic use in cardiovascular disorders where they are able to mediate protective actions. However, one of the major hurdles of therapeutic use of CGRP is that, as a peptide, administration and metabolism are issues. Thus, further work on CGRP agonists as therapy for cardiovascular disorders could reveal potential new drugs and provide more options in the treatment of cardiovascular disease.

\section{AUTHOR CONTRIBUTIONS}

ZK and SDB conceptualized and planned the manuscript. ZK wrote the first draft. All authors reviewed, edited, and approved the final version of the manuscript.

\section{FUNDING}

XK was supported by Arthritis Research UK (ARUK 21541). Some of the studies described in this review were supported by the BBSRC (BB/P005616/1) and the BHF (PG/12/34/29557).

in congestive heart failure. J. Am. Coll. Cardiol. 17, 208-217. doi: 10.1016/07351097(91)90729-S

Ashina, M., Bendtsen, L., Jensen, R., Schifter, S., and Olesen, J. (2000). Evidence for increased plasma levels of calcitonin gene-related peptide in migraine outside of attacks. Pain 86, 133-138. doi: 10.1016/S0304-3959(00)00 232-3

Aubdool, A. A., Kodji, X., Abdul-Kader, N., Heads, R., Fernandes, E. S., Bevan, S., et al. (2016). TRPAl activation leads to neurogenic vasodilatation: involvement of reactive oxygen nitrogen species in addition to CGRP and NO. Br. J. Pharmacol. 173, 2419-2433. doi: 10.1111/bph.13519

Aubdool, A. A., Thakore, P., Argunhan, F., Smillie, S.-J., Schnelle, M., Srivastava, S., et al. (2017). A novel $\alpha$-calcitonin gene-related peptide analogue protects against end-organ damage in experimental hypertension, cardiac hypertrophy, and heart failure. Circulation 136, 367-383. doi: 10.1161/CIRCULATIONAHA. 117.028388 
Bandell, M., Story, G. M., Hwang, S. W., Viswanath, V., Eid, S. R., Petrus, M. J., et al. (2004). Noxious cold ion channel TRPA1 is activated by pungent compounds and bradykinin. Neuron 41, 849-857. doi: 10.1016/S0896-6273(04)00150-3

Bánvölgyi, Á, Pálinkás, L., Berki, T., Clark, N., Grant, A. D., Helyes, Z., et al. (2005). Evidence for a novel protective role of the vanilloid TRPV1 receptor in a cutaneous contact allergic dermatitis model. J. Neuroimmunol. 169, 86-96. doi: 10.1016/j.jneuroim.2005.08.012

Bell, D., and McDermott, B. J. (1996). Calcitonin gene-related peptide in the cardiovascular system: characterization of receptor populations and their (patho)physiological significance. Pharmacol. Rev. 48, 253-288.

Bergdahl, A., Valdemarsson, S., Nilsson, T., Sun, X. Y., Hedner, T., and Edvinsson, L. (1999). Dilatory responses to acetylcholine, calcitonin generelated peptide and substance $\mathrm{P}$ in the congestive heart failure rat. Acta Physiol. Scand. 165, 15-23. doi: 10.1046/j.1365-201x.1999.00456.x

Bigal, M. E., Dodick, D. W., Rapoport, A. M., Silberstein, S. D., Ma, Y., Yang, R., et al. (2015). Safety, tolerability, and efficacy of TEV-48125 for preventive treatment of high-frequency episodic migraine: a multicentre, randomised, double-blind, placebo-controlled, phase $2 \mathrm{~b}$ study. Lancet Neurol. 14, 10811090. doi: 10.1016/S1474-4422(15)00249-5

Bigal, M. E., Walter, S., Bronson, M., Alibhoy, A., and Escandon, R. (2014). Cardiovascular and hemodynamic parameters in women following prolonged CGRP inhibition using LBR-101, a monoclonal antibody against CGRP. Cephalalgia 34, 968-976. doi: 10.1177/0333102414527646

Bodkin, J. V., Thakore, P., Aubdool, A. A., Liang, L., Fernandes, E. S., Nandi, M., et al. (2014). Investigating the potential role of TRPA1 in locomotion and cardiovascular control during hypertension. Pharmacol. Res. Perspect. 2:e00052. doi: $10.1002 /$ prp2.52

Booe, J. M., Warner, M. L., Roehrkasse, A. M., Hay, D. L., and Pioszak, A. A. (2018). Probing the mechanism of receptor activity-modifying protein modulation of GPCR ligand selectivity through rational design of potent adrenomedullin and calcitonin gene-related peptide antagonists. Mol. Pharmacol. 93, 355-367. doi: 10.1124/mol.117.110916

Bracci-Laudiero, L., Aloe, L., Buanne, P., Finn, A., Stenfors, C., Vigneti, E., et al. (2002). NGF modulates CGRP synthesis in human B-lymphocytes: a possible anti-inflammatory action of NGF? J. Neuroimmunol. 123, 58-65. doi: 10.1016/ S0165-5728(01)00475-1

Brain, S. D., and Grant, A. D. (2004). Vascular actions of calcitonin gene-related peptide and adrenomedullin. Physiol. Rev. 84, 903-934. doi: 10.1152/physrev. 00037.2003

Brain, S. D., Williams, T. J., Tippins, J. R., Morris, H. R., and MacIntyre, I. (1985). Calcitonin gene-related peptide is a potent vasodilator. Nature 313, 54-56. doi: $10.1038 / 313054 \mathrm{a} 0$

Bühlmann, N., Leuthäuser, K., Muff, R., Fischer, J. A., and Born, W. (1999). A receptor activity modifying protein (RAMP)2-dependent adrenomedullin receptor is a calcitonin gene-related peptide receptor when coexpressed with human RAMP1. Endocrinology 140, 2883-2890. doi: 10.1210/endo.140.6.6783

Cardinal, R., Nadeau, R., Laurent, C., Boudreau, G., and Armour, J. A. (1996). Reduced capacity of cardiac efferent sympathetic neurons to release noradrenaline and modify cardiac function in tachycardia-induced canine heart failure. Can. J. Physiol. Pharmacol. 74, 1070-1078. doi: 10.1139/y96-112

Caterina, M. J., Schumacher, M. A., Tominaga, M., Rosen, T. A., Levine, J. D., and Julius, D. (1997). The capsaicin receptor: a heat-activated ion channel in the pain pathway. Nature 389, 816-824. doi: 10.1038/39807

Cernuda-Morollón, E., Ramón, C., Martínez-Camblor, P., Serrano-Pertierra, E., Larrosa, D., and Pascual, J. (2015). Onabotulinumtoxin a decreases interictal CGRP plasma levels in patients with chronic migraine. Pain 156, 820-824. doi: 10.1097/j.pain.0000000000000119

Chakravarty, P., Suthar, T. P., Coppock, H. A., Nicholl, C. G., Bloom, S. R., Legon, S., et al. (2000). CGRP and adrenomedullin binding correlates with transcript levels for calcitonin receptor-like receptor (CRLR) and receptor activity modifying proteins (RAMPs) in rat tissues. Br. J. Pharmacol. 130, 189-195. doi: 10.1038/sj.bjp.0702975

Csillik, B., Tajti, L., Kovács, T., Kukla, E., Rakic, P., and Knyihár-Csillik, E. (1993). Distribution of calcitonin gene-related peptide in vertebrate neuromuscular junctions: relationship to the acetylcholine receptor. J. Histochem. Cytochem. 41, 1547-1555. doi: 10.1177/41.10.8245413

Deng, P.-Y., and Li, Y.-J. (2005). Calcitonin gene-related peptide and hypertension. Peptides 26, 1676-1685. doi: 10.1016/j.peptides.2005.02.002
Deng, P.-Y., Ye, F., Cai, W.-J., Deng, H.-W., and Li, Y.-J. (2004). Role of calcitonin gene-related peptide in the phenol-induced neurogenic hypertension in rats. Regul. Pept. 119, 155-161. doi: 10.1016/j.regpep.2004.01.011

Deng, P.-Y., Ye, F., Zhu, H.-Q., Cai, W.-J., Deng, H.-W., and Li, Y.-J. (2003). An increase in the synthesis and release of calcitonin gene-related peptide in two-kidney, one-clip hypertensive rats. Regul. Pept. 114, 175-182. doi: 10.1016/ S0167-0115(03)00124-1

Depre, C., Antalik, L., Starling, A., Koren, M., Eisele, O., Lenz, R. A., et al. (2018). A randomized, double-blind, placebo-controlled study to evaluate the effect of erenumab on exercise time during a treadmill test in patients with stable angina. headache. Headache 58, 715-723. doi: 10.1111/head.13316

Dickerson, I. M. (2013). Role of CGRP-Receptor Component Protein (RCP) in CLR/RAMP function. Curr. Protein Pept. Sci. 14, 407-415. doi: 10.2174/ 13892037113149990057

Dodick, D. W., Ashina, M., Brandes, J. L., Kudrow, D., Lanteri-Minet, M., Osipova, V., et al. (2018a). ARISE: a Phase 3 randomized trial of erenumab for episodic migraine. Cephalalgia 38, 1026-1037. doi: 10.1177/0333102418759786

Dodick, D. W., Silberstein, S. D., Bigal, M. E., Yeung, P. P., Goadsby, P. J., Blankenbiller, T., et al. (2018b). Effect of fremanezumab compared with placebo for prevention of episodic migraine: a randomized clinical trial. JAMA 319, 1999-2008. doi: 10.1001/jama.2018.4853

Dodick, D. W., Goadsby, P. J., Silberstein, S. D., Lipton, R. B., Olesen, J., Ashina, M., et al. (2014). Safety and efficacy of ALD403, an antibody to calcitonin generelated peptide, for the prevention of frequent episodic migraine: a randomised, double-blind, placebo-controlled, exploratory phase 2 trial. Lancet Neurol. 13, 1100-1107. doi: 10.1016/S1474-4422(14)70209-1

Doi, Y., Kudo, H., Nishino, T., Kayashima, K., Kiyonaga, H., Nagata, T., et al. (2001). Synthesis of calcitonin gene-related peptide (CGRP) by rat arterial endothelial cells. Histol. Histopathol. 16, 1073-1079. doi: 10.14670/HH-16. 1073

Dong, Y.-L., Vegiraju, S., Gangula, P. R., Kondapaka, S. B., Wimalawansa, S. J., and Yallampalli, C. (2002). Expression and regulation of calcitonin gene-related Peptide receptor in rat placentas. Biol. Reprod. 67, 1321-1326. doi: 10.1093/ biolreprod/67.4.1321

Doods, H., Hallermayer, G., Wu, D., Entzeroth, M., Rudolf, K., Engel, W., et al. (2000). Pharmacological profile of BIBN4096BS, the first selective small molecule CGRP antagonist. Br. J. Pharmacol. 129, 420-423. doi: 10.1038/sj.bjp. 0703110

Eberhardt, M., Stueber, T., de la Roche, J., Herzog, C., Leffler, A., Reeh, P. W., et al. (2017). TRPA1 and TRPV1 are required for lidocaine-evoked calcium influx and neuropeptide release but not cytotoxicity in mouse sensory neurons. PLoS One 12:e0188008. doi: 10.1371/journal.pone.0188008

Edvinsson, L. (2005). Clinical data on the CGRP antagonist BIBN4096BS for treatment of migraine attacks. CNS Drug Rev. 11, 69-76. doi: 10.1111/j.15273458.2005.tb00036.x

Edvinsson, L., Ekman, R., and Thulin, T. (1989). Reduced levels of calcitonin generelated peptide (CGRP) but not substance $P$ during and after treatment of severe hypertension in man. J. Hum. Hypertens. 3, 267-270.

Edvinsson, L., and Goadsby, P. (1995). Neuropeptides in the cerebral circulation: relevance to headache. Cephalalgia 15, 272-276. doi: 10.1046/j.1468-2982.1995. 1504272.x

Edvinsson, L., Villalón, C. M., and MaassenVanDenBrink, A. (2012). Basic mechanisms of migraine and its acute treatment. Pharmacol. Ther. 136, 319-333. doi: 10.1007/s13311-017-0592-1

Edwards, R. M., and Trizna, W. (1990). Calcitonin gene-related peptide: effects on renal arteriolar tone and tubular cAMP levels. Am. J. Physiol. 258, F121-F125. doi: 10.1152/ajprenal.1990.258.1.F121

Escott, K. J., and Brain, S. D. (1993). Effect of a calcitonin gene-related peptide antagonist (CGRP8-37) on skin vasodilatation and oedema induced by stimulation of the rat saphenous nerve. Br. J. Pharmacol. 110, 772-776. doi: 10.1111/j.1476-5381.1993.tb13878.x

Evans, B. N., Rosenblatt, M. I, Mnayer, L. O., Oliver, K. R., and Dickerson, I. M. (2000). CGRP-RCP, a novel protein required for signal transduction at calcitonin gene-related peptide and adrenomedullin receptors. J. Biol. Chem. 275, 31438-31443. doi: 10.1074/jbc.M005604200

Ferrari, R., Panzali, A. F., Poole-Wilson, P. A., and Anand, S. (1991). Plasma CGRPlike immunoreactivity in treated and untreated congestive heart failure. Lancet 338:1084. doi: 10.1016/0140-6736(91)91944-P 
Franco-Cereceda, A., Henke, H., Lundberg, J. M., Petermann, J. B., Hökfelt, T., and Fischer, J. A. (1987). Calcitonin gene-related peptide (CGRP) in capsaicinsensitive substance P-immunoreactive sensory neurons in animals and man: distribution and release by capsaicin. Peptides 8, 399-410. doi: 10.1016/01969781(87)90117-3

Fujioka, S., Sasakawa, O., Kishimoto, H., Tsumura, K., and Morii, H. (1991). The antihypertensive effect of calcitonin gene-related peptide in rats with norepinephrine- and angiotensin II-induced hypertension. J. Hypertens. 9, 175-179. doi: 10.1097/00004872-199102000-00013

Gao, Y., Song, J., Chen, H., Cao, C., and Lee, C. (2015). TRPV1 activation is involved in the cardioprotection of remote limb ischemic postconditioning in ischemia-reperfusion injury rats. Biochem. Biophys. Res. Commun. 463, 1034-1039. doi: 10.1016/j.bbrc.2015.06.054

Gennari, C., and Fischer, J. A. (1985). Cardiovascular action of calcitonin generelated peptide in humans. Calcif. Tissue Int. 37, 581-584. doi: 10.1007/ BF02554909

Gennari, C., Nami, R., Agnusdei, D., and Fischer, J. A. (1990). Improved cardiac performance with human calcitonin gene related peptide in patients with congestive heart failure. Cardiovasc. Res. 24, 239-241. doi: 10.1093/cvr/24.3.239

Gibbins, I. L., Furness, J. B., Costa, M., MacIntyre, I., Hillyard, C. J., and Girgis, S. (1985). Co-localization of calcitonin gene-related peptide-like immunoreactivity with substance $P$ in cutaneous, vascular and visceral sensory neurons of guinea pigs. Neurosci. Lett. 57, 125-130. doi: 10.1016/0304-3940(85) 90050-3

Goadsby, P. J., Edvinsson, L., and Ekman, R. (1990). Vasoactive peptide release in the extracerebral circulation of humans during migraine headache. Ann. Neurol. 28, 183-187. doi: 10.1002/ana.410280213

Goadsby, P. J., Reuter, U., Hallström, Y., Broessner, G., Bonner, J. H., Zhang, F., et al. (2017). A controlled trial of erenumab for episodic migraine. N. Engl. J. Med. 377, 2123-2132. doi: 10.1056/NEJMoa1705848

Gulbenkian, S., Merighi, A., Wharton, J., Varndell, I. M., and Polak, J. M. (1986). Ultrastructural evidence for the coexistence of calcitonin gene-related peptide and substance $\mathrm{P}$ in secretory vesicles of peripheral nerves in the guinea pig. J. Neurocytol. 15, 535-542. doi: 10.1007/BF01611735

Hay, D. L., Garelja, M. L., Poyner, D. R., and Walker, C. S. (2018). Update on the pharmacology of calcitonin/CGRP family of peptides: IUPHAR review $25 . \mathrm{Br}$. J. Pharmacol. 175, 3-17. doi: 10.1111/bph.14075

Ho, T. W., Connor, K. M., Zhang, Y., Pearlman, E., Koppenhaver, J., Fan, X., et al. (2014). Randomized controlled trial of the CGRP receptor antagonist telcagepant for migraine prevention. Neurology 83, 958-966. doi: 10.1212/ WNL.0000000000000771

Hsu, J.-H., Yeh, J.-L., Dai, Z.-K., Chen, I.-J., and Wu, J.-R. (2005). Increased circulating calcitonin gene-related peptide in congestive heart failure caused by congenital heart disease. Int. Heart J. 46, 867-875. doi: 10.1536/ihj.46.867

Ishikawa, T., Okamura, N., Saito, A., Masaki, T., and Goto, K. (1988). Positive inotropic effect of calcitonin gene-related peptide mediated by cyclic AMP in guinea pig heart. Circ. Res. 63, 726-734. doi: 10.1161/01.RES.63.4.726

Jäger, K., Muench, R., Seifert, H., Beglinger, C., Bollinger, A., and Fischer, J. A. (1990). Calcitonin gene-related peptide (CGRP) causes redistribution of blood flow in humans. Eur. J. Clin. Pharmacol. 39, 491-494. doi: 10.1007/BF00280942

Jancsó, N., Jancsó-GáBor, A., and SzolcsáNyi, J. (1967). Direct evidence for neurogenic inflammation and its prevention by denervation and by pretreatment with capsaicin. Br. J. Pharmacol. Chemother. 31, 138-151. doi: 10.1111/j.1476-5381.1967.tb01984.x

Joyce, C. D., Fiscus, R. R., Wang, X., Dries, D. J., Morris, R. C., and Prinz, R. A. (1990a). Calcitonin gene-related peptide levels are elevated in patients with sepsis. Surgery 108, 1097-1101.

Joyce, C. D., Prinz, R. A., Thomas, J. X., Fiscus, R. R., Wang, X., Djuricin, G., et al. (1990b). Calcitonin gene-related peptide increases coronary flow and decreases coronary resistance. J. Surg. Res. 49, 435-440. doi: 10.1016/00224804(90)90192-5

Juhl, L., Edvinsson, L., Olesen, J., and Jansen-Olesen, I. (2007). Effect of two novel CGRP-binding compounds in a closed cranial window rat model. Eur. J. Pharmacol. 567, 117-124. doi: 10.1016/j.ejphar.2007.04.004

Katori, T., Hoover, D. B., Ardell, J. L., Helm, R. H., Belardi, D. F., Tocchetti, C. G., et al. (2005). Calcitonin gene-related peptide in vivo positive inotropy is attributable to regional sympatho-stimulation and is blunted in congestive heart failure. Circ. Res. 96, 234-243. doi: 10.1161/01.RES.0000152969.42117.ca
Kawasaki, H., Nuki, C., Saito, A., and Takasaki, K. (1990). Role of calcitonin gene-related peptide-containing nerves in the vascular adrenergic neurotransmission. J. Pharmacol. Exp. Ther. 252, 403-409.

Kawasaki, H., Okazaki, M., Nakatsuma, A., Mimaki, Y., Araki, H., and Gomita, Y. (1999). Long-term treatment with angiotensin converting enzyme inhibitor restores reduced calcitonin gene-related peptide-containing vasodilator nerve function in mesenteric artery of spontaneously hypertensive rats. Jpn. J. Pharmacol. 79, 221-229. doi: 10.1254/jjp.79.221

Kawasaki, H., Takenaga, M., Araki, H., Futagami, K., and Gomita, Y. (1998). Angiotensin inhibits neurotransmission of calcitonin gene-related peptide-containing vasodilator nerves in mesenteric artery of spontaneously hypertensive rats. J. Pharmacol. Exp. Ther. 284, 508-515.

Kobayashi, K., Fukuoka, T., Obata, K., Yamanaka, H., Dai, Y., Tokunaga, A., et al. (2005). Distinct expression of TRPM8, TRPA1, and TRPV1 mRNAs in rat primary afferent neurons with adelta/c-fibers and colocalization with trk receptors. J. Comp. Neurol. 493, 596-606. doi: 10.1002/cne.20794

Kraenzlin, M. E., Ch'ng, J. L., Mulderry, P. K., Ghatei, M. A., and Bloom, S. R. (1985). Infusion of a novel peptide, calcitonin gene-related peptide (CGRP) in man. Pharmacokinetics and effects on gastric acid secretion and on gastrointestinal hormones. Regul. Pept. 10, 189-197. doi: 10.1016/01670115(85)90013-8

Kurihara, H., Shindo, T., Oh-Hashi, Y., Kurihar, Y., and Kuwaki, T. (2003). Targeted disruption of adrenomedullin and alphaCGRP genes reveals their distinct biological roles. Hypertens. Res. 26(Suppl.), S105-S108. doi: 10.1291/ hypres.26.S105

Kurtz, A., Schurek, H. J., Jelkmann, W., Muff, R., Lipp, H. P., Heckmann, U., et al. (1989). Renal mesangium is a target for calcitonin gene-related peptide. Kidney Int. 36, 222-227. doi: 10.1038/ki.1989.183

Kuwasako, K., Cao, Y.-N., Chu, C.-P., Iwatsubo, S., Eto, T., and Kitamura, K. (2006). Functions of the cytoplasmic tails of the human receptor activitymodifying protein components of calcitonin gene-related peptide and adrenomedullin receptors. J. Biol. Chem. 281, 7205-7213. doi: 10.1074/jbc. M511147200

Li, J., Levick, S. P., DiPette, D. J., Janicki, J. S., and Supowit, S. C. (2013). Alphacalcitonin gene-related peptide is protective against pressure overload-induced heart failure. Regul. Pept. 185, 20-28. doi: 10.1016/j.regpep.2013.06.008

Li, J., and Wang, D. H. (2005). Development of angiotensin II-induced hypertension: role of CGRP and its receptor. J. Hypertens. 23, 113-118. doi: 10.1097/00004872-200501000-00020

Li, J., Zhao, H., Supowit, S. C., Dipette, D. J., and Wang, D. H. (2004). Activation of the renin-angiotensin system in alpha-calcitonin generelated peptide/calcitonin gene knockout mice. J. Hypertens. 22, 1345-1349. doi: 10.1097/01.hjh.0000125409.50839.f1

Li, J.-Z., Peng, J., Xiao, L., Zhang, Y.-S., Liao, M.-C., Li, X.-H., et al. (2010). Reversal of isoprenaline-induced cardiac remodeling by rutaecarpine via stimulation of calcitonin gene-related peptide production. Can. J. Physiol. Pharmacol. 88, 949-959. doi: 10.1139/y10-067

Li, Y. J., Xiao, Z. S., Peng, C. F., and Deng, H. W. (1996). Calcitonin gene-related peptide-induced preconditioning protects against ischemia-reperfusion injury in isolated rat hearts. Eur. J. Pharmacol. 311, 163-167. doi: 10.1016/00142999(96)00426-8

Lind, H., Brudin, L., Lindholm, L., and Edvinsson, L. (1996). Different levels of sensory neuropeptides (calcitonin gene-related peptide and substance $\mathrm{P}$ ) during and after exercise in man. Clin. Physiol. 16, 73-82. doi: 10.1111/j.1475-097X. 1996.tb00557.x

Linscheid, P., Seboek, D., Schaer, D. J., Zulewski, H., Keller, U., and Müller, B. (2004). Expression and secretion of procalcitonin and calcitonin gene-related peptide by adherent monocytes and by macrophage-activated adipocytes. Crit. Care Med. 32, 1715-1721. doi: 10.1097/01.CCM.0000134404.632 92.71

Liu, Z., Liu, Q., Cai, H., Xu, C., Liu, G., and Li, Z. (2011). Calcitonin gene-related peptide prevents blood-brain barrier injury and brain edema induced by focal cerebral ischemia reperfusion. Regul. Pept. 171, 19-25. doi: 10.1016/j.regpep. 2011.05.014

Ludman, P. F., Maseri, A., Clark, P., and Davies, G. J. (1991). Effects of calcitonin gene-related peptide on normal and atheromatous vessels and on resistance vessels in the coronary circulation in humans. Circulation 84, 1993-2000. doi: 10.1161/01.CIR.84.5.1993 
Lundberg, J. M., Franco-Cereceda, A., Hua, X., Hökfelt, T., and Fischer, J. A. (1985). Co-existence of substance $\mathrm{P}$ and calcitonin gene-related peptidelike immunoreactivities in sensory nerves in relation to cardiovascular and bronchoconstrictor effects of capsaicin. Eur. J. Pharmacol. 108, 315-319. doi: 10.1016/0014-2999(85)90456-X

Lundberg, J. M., Hua, Y., and Fredholm, B. B. (1984). Capsaicin-induced stimulation of the guinea-pig atrium. Naunyn Schmiedebergs Arch. Pharmacol. 325, 176-182. doi: 10.1007/BF00506198

MaassenVanDenBrink, A., Meijer, J., Villalón, C. M., and Ferrari, M. D. (2016). Wiping out CGRP: potential cardiovascular risks. Trends Pharmacol. Sci. 37, 779-788. doi: 10.1016/j.tips.2016.06.002

Mai, T., Wu, J., Diedrich, A., Garland, E. M., and Robertson, D. (2014). Calcitonin gene related peptide (CGRP) in autonomic cardiovascular regulation and vascular structure. J. Am. Soc. Hypertens. 8, 286-296. doi: 10.1016/j.jash.2014. 03.001

Marshall, I., Al-Kazwini, S., Holman, J., and Craig, R. (1988). Human alphacalcitonin gene-related peptide (CGRP) is a potent vasodilator in human mesenteric vasculature. Br. J. Clin. Pharmacol. 26, 691-695. doi: 10.1111/j.13652125.1988.tb05306.x

Marshall, N. J., Liang, L., Bodkin, J., Dessapt-Baradez, C., Nandi, M., CollotTeixeira, S., et al. (2013). A role for TRPV1 in influencing the onset of cardiovascular disease in obesity. Hypertension 61, 246-252. doi: 10.1161/ HYPERTENSIONAHA.112.201434

Masuda, A., Shimamoto, K., Mori, Y., Nakagawa, M., Ura, N., and Iimura, O. (1992). Plasma calcitonin gene-related peptide levels in patients with various hypertensive diseases. J. Hypertens. 10, 1499-1504. doi: 10.1097/00004872199210120-00010

Matteoli, M., Haimann, C., Torri-Tarelli, F., Polak, J. M., Ceccarelli, B., and De Camilli, P. (1988). Differential effect of alpha-latrotoxin on exocytosis from small synaptic vesicles and from large dense-core vesicles containing calcitonin gene-related peptide at the frog neuromuscular junction. Proc. Natl. Acad. Sci. U.S.A. 85, 7366-7370. doi: 10.1073/pnas.85.19.7366

McLatchie, L. M., Fraser, N. J., Main, M. J., Wise, A., Brown, J., Thompson, N., et al. (1998). RAMPs regulate the transport and ligand specificity of the calcitonin-receptor-like receptor. Nature 393, 333-339. doi: 10.1038/30666

Meens, M. J., Mattheij, N. J., van Loenen, P. B., Spijkers, L. J., Lemkens, P., Nelissen, J., et al. (2012). G-protein $\beta \gamma$ subunits in vasorelaxing and antiendothelinergic effects of calcitonin gene-related peptide. Br. J. Pharmacol. 166, 297-308. doi: 10.1111/j.1476-5381.2011.01774.x

Messlinger, K. (2018). The big CGRP flood - sources, sinks and signalling sites in the trigeminovascular system. J. Headache Pain 19:22. doi: 10.1186/s10194-0180848-0

Mishima, T., Ito, Y., Hosono, K., Tamura, Y., Uchida, Y., Hirata, M., et al. (2011). Calcitonin gene-related peptide facilitates revascularization during hindlimb ischemia in mice. Am. J. Physiol. Heart Circ. Physiol. 300, H431-H439. doi: 10.1152/ajpheart.00466.2010

Moreno, M. J., Terrón, J. A., Stanimirovic, D. B., Doods, H., and Hamel, E. (2002). Characterization of calcitonin gene-related peptide (CGRP) receptors and their receptor-activity-modifying proteins (RAMPs) in human brain microvascular and astroglial cells in culture. Neuropharmacology 42, 270-280. doi: 10.1016/ S0028-3908(01)00176-9

Mulderry, P. K., Ghatei, M. A., Bishop, A. E., Allen, Y. S., Polak, J. M., and Bloom, S. R. (1985). Distribution and chromatographic characterisation of CGRP-like immunoreactivity in the brain and gut of the rat. Regul. Pept. 12, 133-143. doi: 10.1016/0167-0115(85)90194-6

Nakajima, T., Takikawa, R., Sugimoto, T., and Kurachi, Y. (1991). Effects of calcitonin gene-related peptide on membrane currents in mammalian cardiac myocytes. Pflugers Arch. 419, 644-650. doi: 10.1007/BF00370309

Nilsson, C., Hansen, T. K., Rosenquist, C., Hartmann, B., Kodra, J. T., Lau, J. F., et al. (2016). Long acting analogue of the calcitonin gene-related peptide induces positive metabolic effects and secretion of the glucagon-like peptide- 1 . Eur. J. Pharmacol. 773, 24-31. doi: 10.1016/j.ejphar.2016.01.003

O'Connor, T. P., and van der Kooy, D. (1988). Enrichment of a vasoactive neuropeptide (calcitonin gene related peptide) in the trigeminal sensory projection to the intracranial arteries. J. Neurosci. 8, 2468-2476. doi: 10.1523/ JNEUROSCI.08-07-02468.1988

Olesen, J., Diener, H.-C., Husstedt, I. W., Goadsby, P. J., Hall, D., Meier, U., et al. (2004). Calcitonin gene-related peptide receptor antagonist BIBN 4096
BS for the acute treatment of migraine. N. Engl. J. Med. 350, 1104-1110. doi: 10.1056/NEJMoa030505

Ozaka, T., Doi, Y., Kayashima, K., and Fujimoto, S. (1997). Weibel-Palade bodies as a storage site of calcitonin gene-related peptide and endothelin-1 in blood vessels of the rat carotid body. Anat. Rec. 247, 388-394. doi: 10.1002/(SICI) 1097-0185(199703)247:3<388::AID-AR10>3.0.CO;2-L

Paemeleire, K., and MaassenVanDenBrink, A. (2018). Calcitonin-gene-related peptide pathway mAbs and migraine prevention. Curr. Opin. Neurol. 31, 274-280. doi: 10.1097/WCO.0000000000000548

Portaluppi, F., Trasforini, G., Margutti, A., Vergnani, L., Ambrosio, M. R., Rossi, R., et al. (1992). Circadian rhythm of calcitonin gene-related peptide in uncomplicated essential hypertension. J. Hypertens. 10, 1227-1234. doi: 10.1097/00004872-199210000-00017

Pozsgai, G., Hajna, Z., Bagoly, T., Boros, M., Kemény, Á, Materazzi, S., et al. (2012). The role of transient receptor potential ankyrin 1 (TRPA1) receptor activation in hydrogen-sulphide-induced CGRP-release and vasodilation. Eur. J. Pharmacol. 689, 56-64. doi: 10.1016/j.ejphar.2012.05.053

Preibisz, J. J. (1993). Calcitonin gene-related peptide and regulation of human cardiovascular homeostasis. Am. J. Hypertens. 6, 434-450. doi: 10.1093/ajh/6. 5.434

Qi, T., Ly, K., Poyner, D. R., Christopoulos, G., Sexton, P. M., and Hay, D. L. (2011). Structure-function analysis of amino acid 74 of human RAMP1 and RAMP3 and its role in peptide interactions with adrenomedullin and calcitonin generelated peptide receptors. Peptides 32, 1060-1067. doi: 10.1016/j.peptides.2011. 03.004

Quallo, T., Gentry, C., Bevan, S., Broad, L. M., and Mogg, A. J. (2015). Activation of transient receptor potential ankyrin 1 induces CGRP release from spinal cord synaptosomes. Pharmacol. Res. Perspect. 3:e00191. doi: 10.1002/prp 2.191

Raffaelli, B., and Reuter, U. (2018). The biology of monoclonal antibodies: focus on calcitonin gene-related peptide for prophylactic migraine therapy. Neurotherapeutics 15, 324-335. doi: 10.1007/s13311-018-0622-7

Rosenfeld, M. G., Mermod, J.-J., Amara, S. G., Swanson, L. W., Sawchenko, P. E., Rivier, J., et al. (1983). Production of a novel neuropeptide encoded by the calcitonin gene via tissue-specific RNA processing. Nature 304, 129-135. doi: $10.1038 / 304129 \mathrm{a} 0$

Roudenok, V., Gutjar, L., Antipova, V., and Rogov, Y. (2001). Expression of vasoactive intestinal polypeptide and calcitonin gene-related peptide in human stellate ganglia after acute myocardial infarction. Ann. Anat. 183, 341-344. doi: 10.1016/S0940-9602(01)80176-X

Russell, F. A., King, R., Smillie, S.-J., Kodji, X., and Brain, S. D. (2014). Calcitonin gene-related peptide: physiology and pathophysiology. Physiol. Rev. 94, 10991142. doi: 10.1152/physrev.00034.2013

Sacco, S., and Kurth, T. (2014). Migraine and the risk for stroke and cardiovascular disease. Curr. Cardiol. Rep. 16:524. doi: 10.1007/s11886-014-0524-1

Schifter, S., Krusell, L. R., and Sehested, J. (1991). Normal serum levels of calcitonin gene-related peptide (CGRP) in mild to moderate essential hypertension. Am. J. Hypertens. 4, 565-569. doi: 10.1093/ajh/4.7.565

Schlereth, T., Schukraft, J., Krämer-Best, H. H., Geber, C., Ackermann, T., and Birklein, F. (2016). Interaction of calcitonin gene related peptide (CGRP) and substance P (SP) in human skin. Neuropeptides 59, 57-62. doi: 10.1016/j.npep. 2016.06.001

Sekiguchi, N., Kanatsuka, H., Sato, K., Wang, Y., Akai, K., Komaru, T., et al. (1994). Effect of calcitonin gene-related peptide on coronary microvessels and its role in acute myocardial ischemia. Circulation 89, 366-374. doi: 10.1161/01.CIR.89. 1.366

Shang, S., Zhu, F., Liu, B., Chai, Z., Wu, Q., Hu, M., et al. (2016). Intracellular TRPA1 mediates $\mathrm{Ca} 2+$ release from lysosomes in dorsal root ganglion neurons. J. Cell Biol. 215, 369-381. doi: 10.1083/jcb.201603081

Shekhar, Y. C., Anand, I. S., Sarma, R., Ferrari, R., Wahi, P. L., and PooleWilson, P. A. (1991). Effects of prolonged infusion of human alpha calcitonin gene-related peptide on hemodynamics, renal blood flow and hormone levels in congestive heart failure. Am. J. Cardiol. 67, 732-736. doi: 10.1016/00029149(91)90531-O

Sheykhzade, M., Abdolalizadeh, B., Koole, C., Pickering, D. S., Dreisig, K., Johansson, S. E., et al. (2018). Vascular and molecular pharmacology of the metabolically stable CGRP analogue, SAX. Eur. J. Pharmacol. 829, 85-92. doi: 10.1016/j.ejphar.2018.04.007 
Sigrist, S., Franco-Cereceda, A., Muff, R., Henke, H., Lundberg, J. M., and Fischer, J. A. (1986). Specific receptor and cardiovascular effects of calcitonin generelated peptide. Endocrinology 119, 381-389. doi: 10.1210/endo-119-1-381

Singh, A., Randhawa, P. K., Bali, A., Singh, N., and Jaggi, A. S. (2017). Exploring the role of TRPV and CGRP in adenosine preconditioning and remote hind limb preconditioning-induced cardioprotection in rats. Cardiovasc. Drugs Ther. 31, 133-143. doi: 10.1007/s10557-017-6716-3

Smillie, S.-J., and Brain, S. D. (2011). Calcitonin gene-related peptide (CGRP) and its role in hypertension. Neuropeptides 45, 93-104. doi: 10.1016/j.npep.2010. 12.002

Smillie, S.-J., King, R., Kodji, X., Outzen, E., Pozsgai, G., Fernandes, E., et al. (2014). An ongoing role of $\alpha$-calcitonin gene-related peptide as part of a protective network against hypertension, vascular hypertrophy, and oxidative stress. Hypertension 63, 1056-1062. doi: 10.1161/HYPERTENSIONAHA.113. 02517

Song, S. W., Guo, K. J., Shi, R., Cheng, Y., and Liu, Y. F. (2009). Pretreatment with calcitonin gene-related peptide attenuates hepatic ischemia/reperfusion injury in rats. Transplant. Proc. 41, 1493-1498. doi: 10.1016/j.transproceed.2009.03. 056

Stauffer, V. L., Dodick, D. W., Zhang, Q., Carter, J. N., Ailani, J., and Conley, R. R. (2018). Evaluation of galcanezumab for the prevention of episodic migraine: the EVOLVE-1 randomized clinical trial. JAMA Neurol. doi: 10.1001/jamaneurol. 2018.1212 [Epub ahead of print].

Struthers, A. D., Brown, M. J., Macdonald, D. W. R., Beacham, J. L., Stevenson, J. C., Morris, H. R., et al. (1986). Human calcitonin gene related peptide: a potent endogenous vasodilator in man. Clin. Sci. 70, 389-393. doi: 10.1042/cs0700389

Supowit, S. C., Ramana, C. V., Westlund, K. N., and Di Pette, D. J. (1993). Calcitonin gene-related peptide gene expression in the spontaneously hypertensive rat. Hypertension 21, 1010-1014. doi: 10.1161/01.HYP.21.6.1010

Supowit, S. C., Zhao, H., Hallman, D. M., and DiPette, D. J. (1997). Calcitonin gene-related peptide is a depressor of deoxycorticosterone-salt hypertension in the rat. Hypertension 29, 945-950. doi: 10.1161/01.HYP.29.4.945

Takenaga, M., and Kawasaki, H. (1999). Endogenous calcitonin gene-related peptide suppresses vasoconstriction mediated by adrenergic nerves in rat mesenteric resistance blood vessels. Eur. J. Pharmacol. 367, 239-245. doi: 10.1016/S0014-2999(98)00949-2

Taquet, H., Komajda, M., Grenier, O., Belas, F., Landault, C., Carayon, A., et al. (1992). Plasma calcitonin gene-related peptide decreases in chronic congestive heart failure. Eur. Heart J. 13, 1473-1476. doi: 10.1093/oxfordjournals. eurheartj.a060088

Terenghi, G., Polak, J. M., Ghatei, M. A., Mulderry, P. K., Butler, J. M., Unger, W. G., et al. (1985). Distribution and origin of calcitonin gene-related peptide (CGRP) immunoreactivity in the sensory innervation of the mammalian eye. J. Comp. Neurol. 233, 506-516. doi: 10.1002/cne.902330410

Tortorella, C., Macchi, C., Forneris, M., and Nussdorfer, G. G. (2001). Calcitonin gene-related peptide (CGRP), acting via CGRP type 1 receptors, inhibits potassium-stimulated aldosterone secretion and enhances basal catecholamine secretion from rat adrenal gland. Int. J. Mol. Med. 8, 261-264. doi: 10.3892/ ijmm.8.3.261

Van der Schueren, B. J., Rogiers, A., Vanmolkot, F. H., Van Hecken, A., Depré, M., Kane, S. A., et al. (2008). Calcitonin gene-related peptide8-37 antagonizes capsaicin-induced vasodilation in the skin: evaluation of a human in vivo pharmacodynamic model. J. Pharmacol. Exp. Ther. 325, 248-255. doi: 10.1124/ jpet.107.133868

Vatner, D. E., Sato, N., Ishikawa, Y., Kiuchi, K., Shannon, R. P., and Vatner, S. F. (1996). Beta-adrenoceptor desensitization during the development of canine pacing-induced heart failure. Clin. Exp. Pharmacol. Physiol. 23, 688-692. doi: 10.1111/j.1440-1681.1996.tb01760.x

Venkatachalam, K., and Montell, C. (2007). TRP Channels. Annu. Rev. Biochem. 76, 387-417. doi: 10.1146/annurev.biochem.75.103004.142819

Viana, F. (2016). TRPA1 channels: molecular sentinels of cellular stress and tissue damage. J. Physiol. 594, 4151-4169. doi: 10.1113/JP270935

Wang, H., Xing, L., Li, W., Hou, L., Guo, J., and Wang, X. (2002). Production and secretion of calcitonin gene-related peptide from human lymphocytes. J. Neuroimmunol. 130, 155-162. doi: 10.1016/S0165-5728(02)00 221-7

Wang, W., Zhu, G.-Q., Gao, L., Tan, W., and Qian, Z.-M. (2004). Baroreceptor reflex in heart failure. Sheng Li Xue Bao 56, 269-281.

Weston, C., Winfield, I., Harris, M., Hodgson, R., Shah, A., Dowell, S. J., et al. (2016). Receptor activity-modifying protein-directed g protein signaling specificity for the calcitonin gene-related peptide family of receptors. J. Biol. Chem. 291, 21925-21944. doi: 10.1074/jbc.M116.751362

Wolfrum, S., Nienstedt, J., Heidbreder, M., Schneider, K., Dominiak, P., and Dendorfer, A. (2005). Calcitonin gene related peptide mediates cardioprotection by remote preconditioning. Regul. Pept. 127, 217-224. doi: 10.1016/j.regpep.2004.12.008

Yao, G., Yu, T., Han, X., Mao, X., and Li, B. (2013). Therapeutic effects and safety of olcegepant and telcagepant for migraine: a meta-analysis. Neural Regen. Res. 8, 938-947. doi: 10.3969/j.issn.1673-5374.2013.10.009

Zaidi, M., Brain, S. D., Tippins, J. R., Di Marzo, V., Moonga, B. S., Chambers, T. J., et al. (1990). Structure-activity relationship of human calcitonin-gene-related peptide. Biochem. J. 269, 775-780. doi: 10.1042/bj269 0775

Zeller, J., Poulsen, K. T., Sutton, J. E., Abdiche, Y. N., Collier, S., Chopra, R., et al. (2008). CGRP function-blocking antibodies inhibit neurogenic vasodilatation without affecting heart rate or arterial blood pressure in the rat. Br. J. Pharmacol. 155, 1093-1103. doi: 10.1038/bjp.2008.334

Zheng, J. (2013). Molecular mechanism of TRP channels. Compr. Physiol. 3, 221-242. doi: 10.1002/cphy.c120001

Conflict of Interest Statement: SDB is a consultant for Eli Lilly.

The remaining authors declare that the research was conducted in the absence of any commercial or financial relationships that could be construed as a potential conflict of interest.

Copyright (c) 2018 Kee, Kodji and Brain. This is an open-access article distributed under the terms of the Creative Commons Attribution License (CC BY). The use, distribution or reproduction in other forums is permitted, provided the original author(s) and the copyright owner(s) are credited and that the original publication in this journal is cited, in accordance with accepted academic practice. No use, distribution or reproduction is permitted which does not comply with these terms. 